\title{
Groundwater Effect on Slope Stability in Open Pit Mining: a Case of West Kutai Regency, East Kalimantan, Indonesia
}

\author{
Shalaho Dina Devy ${ }^{1, *}$, Pretty Permatasari Hutahayan ${ }^{1}$ \\ ${ }_{1}^{1}$ Mining Engineering Department, Faculty of Engineering, Mulawarman University, Samarinda, Indonesia
}

* Corresponding author : shalaho.d2@gmail.com

Tel.:+628125848054;

Received: Jan 13, 2021; Accepted: Dec 24, 2021.

DOI: $10.25299 /$ jgeet.2021.6.4.6226

\begin{abstract}
The stability of open pit slopes in Biangan district, West Kutai Regency, East Kalimantan Province, is greatly influenced by groundwater conditions. The existence of groundwater reduces the shear strength of the materials which causes a decrease in the stability value of pit slopes. The main objective of this study is to assess the impact of groundwater on the stability of the low wall and high wall pit mining. Groundwater modeling is used to determine the prediction of groundwater level on the pit slope which determines the value of the slope stability. Slope stability analysis in this study was performed using the Finite Element Method, producing output in the form of strain zones, deformation and displacement values. Therefore, the Strength Reduction Factor (SRF) approach was used, which is a gradual reduction of shear strength until the values of cohesion and friction angles reach minimums and the slopes are at a critical state. Groundwater modeling results indicate that groundwater flows to the Biangan river with hydraulic heads between 76 and 108 meters above sea level. Based on the analysis using the Finite Element Method, the stability values of the pit slopes, which are influenced by groundwater, are 0.65 on the low wall and 1.40 on the high wall. The total displacements are 0.019 meters on the low wall and 0.002 meters on the high wall. The impact of groundwater on the slope is an increase in the slope load. This increases the materials' thrust and reduces the shear strength of the materials which reduces the rock mass that can function as a water seepage path. Thus, the recommendation for low wall pit construction is a safety factor of 7.79 with a total displacement of 0.020 meters.
\end{abstract}

Keywords: Finite Element Method, Groundwater Modelling, Slope Stability, West Kutai

\section{Introduction}

Slope stability is one of the important factors that affect coal mining activities, the slope of the mining slope is steep, and the mining is deeper, resulting in increasingly unstable slopes. Apart from being influenced by these factors, the stability of a slope is also influenced by other factors, such as: the value of the rock strength possessed by each slope constituent material, slope geometry, and groundwater can also affect slope stability.

Groundwater is in a saturated layer, so groundwater greatly affects the stability value of a slope. The groundwater condition affects the value of the shear strength in the material which causes a decrease in the value of slope stability. Slope stability analysis needs to be done to find the safe value of the Safety Factor on the low wall and high walls of the open pit mine.

Slope stability analysis, which is affected by groundwater on the high wall and low wall, is carried out using the Finite Element Method while the value of Safety Factor of the slopes is by using the Strength Reduction Factor (SRF) approach (Hustrulid et al., 2001).

The purpose of this study was to determine groundwater modeling, analyze the overall slope of the low wall and high wall slopes in the pit which is influenced by groundwater and determine the value of the Critical SRF or safe Safety Factor on the low wall and high wall pit slopes in Biangan open pit mining.

\section{Methods.}

The method used for this study was an inductive method that began with observation and literature study that was used as a recommendation. The approach used was an analytical approach that included hydrological, hydrogeological studies in the form of aquifers, geotechnical and pit design. (1) hydrological data including rainfall calculation and watershed, (2) hydrogeological data including data of geology, geomorphology, determining hydraulic conductivity values in piezometer holes obtained. from slug test, run-off, evapotranspiration, groundwater recharge and aquifer sub-surface values. The equation for calculating these data can be seen in Table 1, and (3) geotechnical data including data of material strength, slope geometry to the lithology of the material making up the slope. Hydrological data and geohydrological data are used for groundwater modelling analysis, while geotechnical data is for the analysis of high wall and low wall at the mine pit area (Haq et al., 2011).

Biangan district is one of the important districts in the West Kutai region which is the center of open-pit mining activities. The district is located between $0^{\circ} 00^{\prime \prime}-0^{\circ} 15^{\prime \prime} \mathrm{N}$ Latitudes and $115^{\circ} 25^{\prime \prime}-115^{\circ} 45^{\prime \prime}$ E Longitudes.

The geology of the study area is included in the Pulaubalang Formation (Tmpb) composed of rock in the form of interlocking quartz and sandstones, siltstone, siltstone with limestone, tuff and coal insertions. Sandstone quartz (fine - medium), disaggregated good, some tuffaceous and calcareous, carbonaceous, local alternating with siltstone and mudstone thickness of $15 \mathrm{~cm}$, bedding parallel (fine - medium), locally calcareous, pieces of coal, local Interspersed with the claystone grey and sandstone. 
The unit age is estimated to be Middle Miocene (Fig. 1). Depositional environments terrestrial - shallow sea. The layer thickness of approximately 2,500 m (Supriyatna and Rustandi, 1995).

Geomorphology is dominated by hills which are indicated with dense contour lines. The study area has an average slope of $27.2 \%$, which is the relief of hilly topography and classified as the steep slope (van Zuidam and van Zuidam-Cancelado, 1979). The topographic map
(Fig. 2) shows the study area with an area of $11,745 \mathrm{~km}^{2}$ and the highest elevation is in the southern hills with an altitude of $+170 \mathrm{~m} \mathrm{ASL}$, while the lowest elevation is in the northern part with an altitude of $+81 \mathrm{~m}$ ASL. The climate of the research area is categorized as the tropical with an average temperature of $26^{\circ} \mathrm{C}-35^{\circ} \mathrm{C}$ and the lowest temperature is in July and August. The average rainfall is 2,668 $\mathrm{mm}$ with moderate to high rainfall conditions in August - March and low in April - September (Devy, 2018).

Table 1. Hydrological data and equation

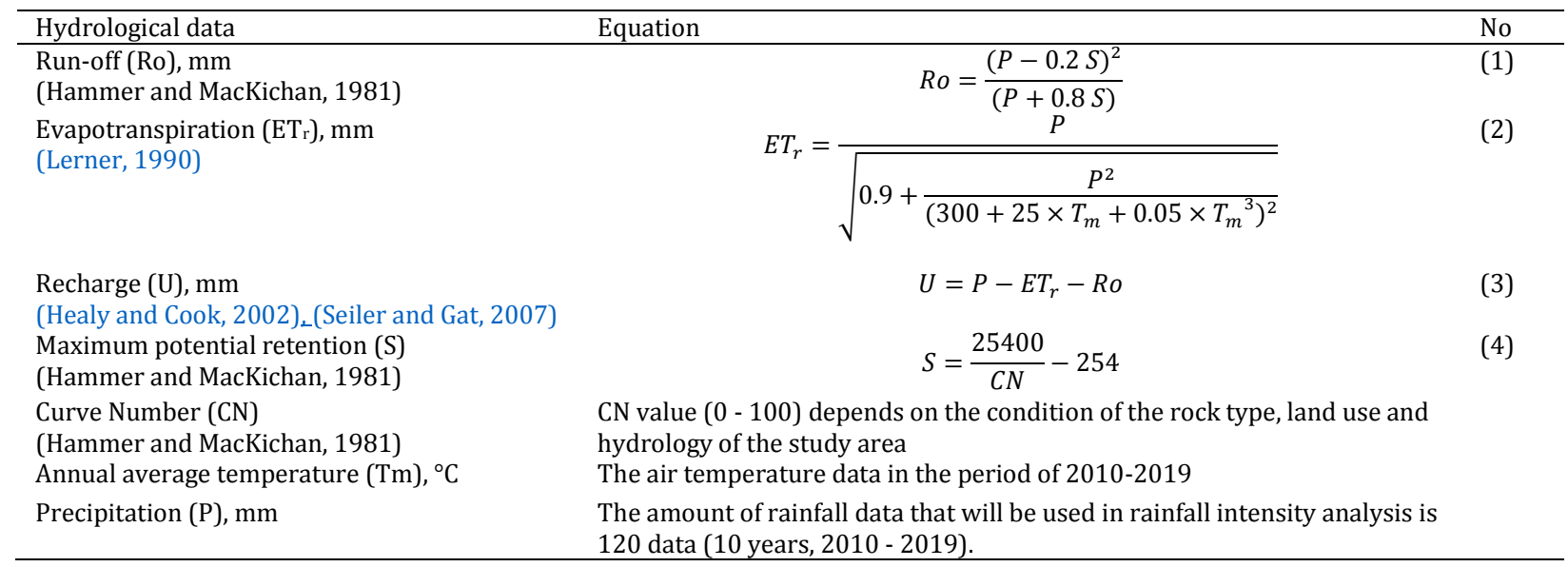

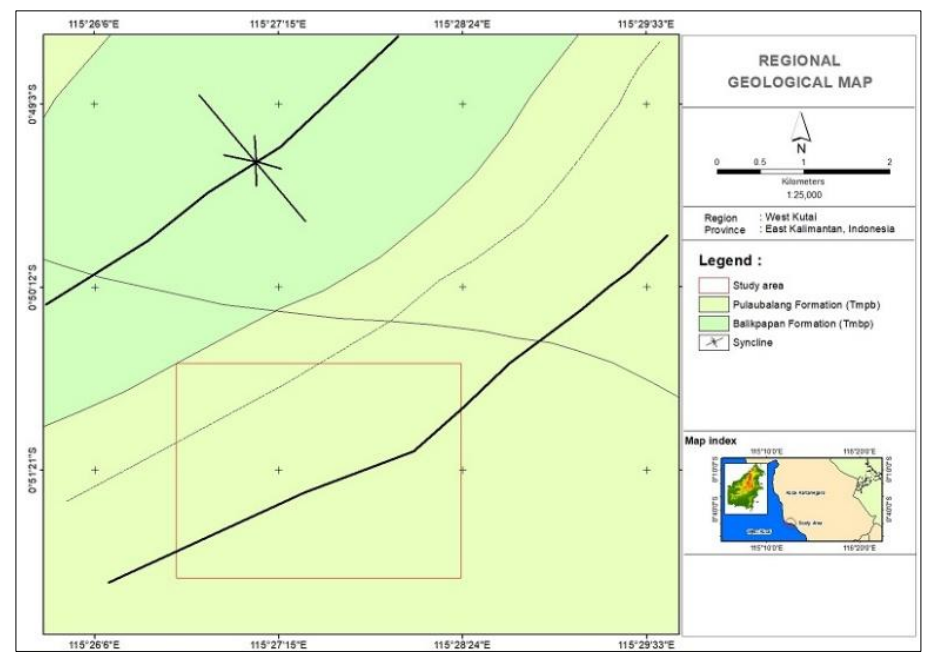

Fig 1. Regional geological map

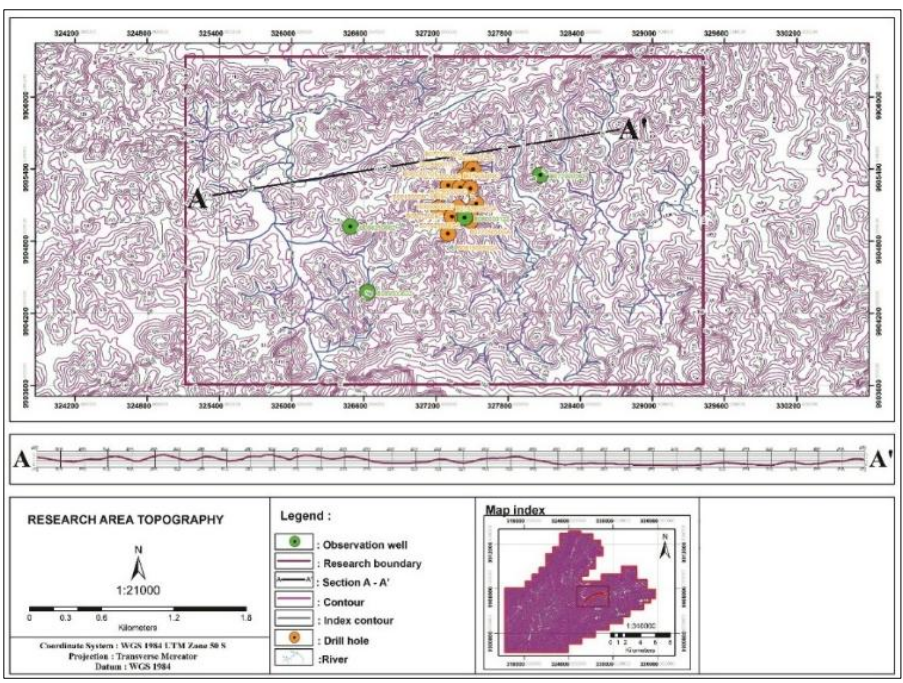

Fig 2. Research area topography 


\section{Result and Discussions}

\subsection{Watersheds}

The research area is located at the area of Pahu Amis and Biangan river and watershed. The Biangan watershed is depicted by pink polygons with an area of 3,056 $\mathrm{km}^{2}$, while the Pahu Amis is in yellow polygons with an area of $5,847 \mathrm{~km}^{2}$. Hence, the total area of watersheds in the study area is $8,903 \mathrm{~km}^{2}$ (Fig. 3). The area of the watershed is used

as a research boundary in groundwater recharge calculations (Fetter, 2001). In the study area, there is a catchment area of $1.89 \mathrm{~km}^{2}$ area bounded by the highest elevation around the mine opening. Rain is expected to fall on the flow area and will be accumulated around the mine opening (sump) and the open channel.

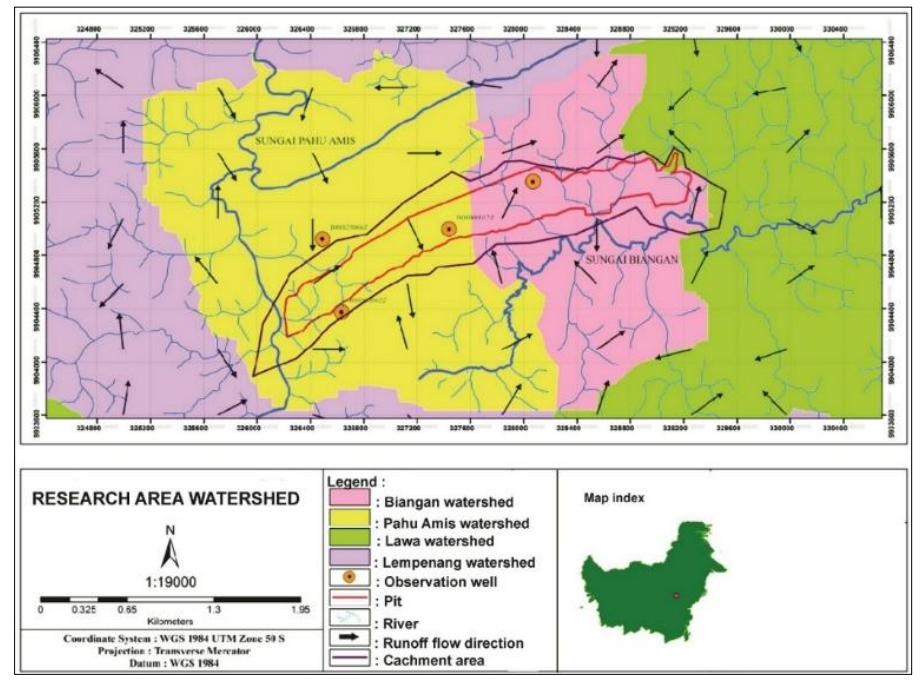

Fig 3. Research area watershed

\subsection{Types of Aquifers}

Analysis of aquifer characteristics aims to determine the value of hydraulic conductivity (Harbaugh, 2005). Hydraulic conductivity is obtained from the slug test on the piezometric hole which is used as a groundwater observation wells in the study area (Fig. 4). The hydraulic conductivity $(\mathrm{K})$ value of the aquifer layer resulting from the slug test can be seen in Table 2 .

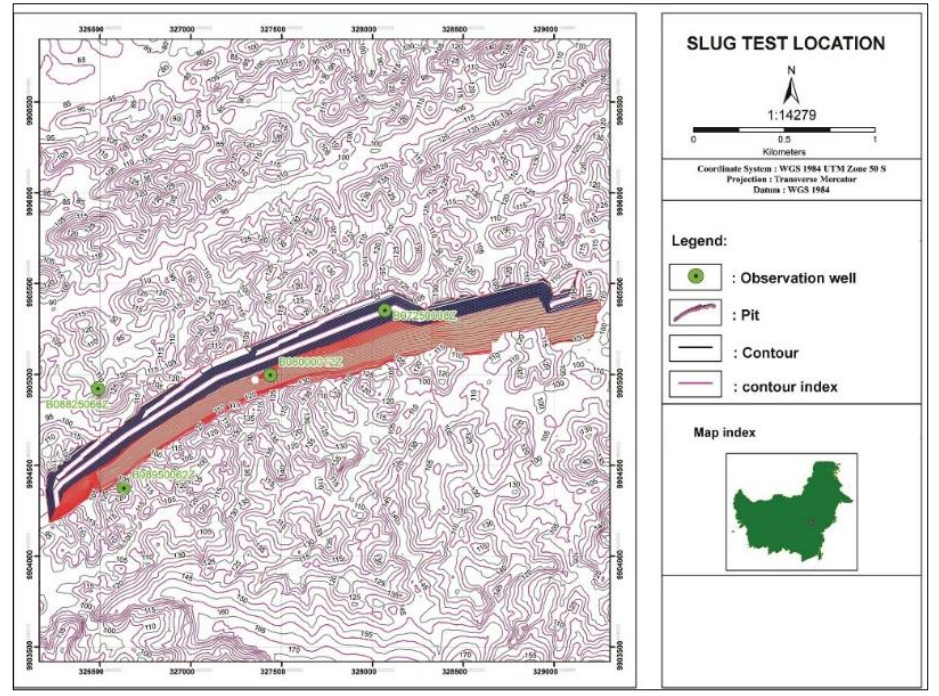

Fig 4. Slug test location

Table 2. Hydraulic conductivity of piezometric wells

\begin{tabular}{llllll}
\hline No. & ID Holes & ID Piezometer & material type & K $(\mathrm{m} / \mathrm{sec})$ & Aquafer type \\
\hline 1 & B07250008Z & PZ 02 & Coal & $4.68 \times 10^{-7}$ & Aquitard \\
2 & B08000012Z & PZ 03 & Silty sandstone & $1.20 \times 10^{-6}$ & Aquifer \\
3 & B08825066Z & PZ 05 & Sandstone & $1.10 \times 10^{-5}$ & Aquifer \\
4 & B08950062Z & PZ 06 & Sandstone & $1.11 \times 10^{-4}$ & Aquifer \\
\hline
\end{tabular}

Hydraulic conductivity is the velocity of liquid flow on a porous media in a saturated state or it can also be said to be the speed of water flow at a certain period in meters per second. The greater the value of hydraulic conductivity, the 
greater the ability of rocks to carry on water (Konikow and Reilly, 1999) (Fabbri et al., 2012). Based on the results of the analysis through the obtained data, it is found out that the distribution of aquifers in the study area is a semiconfined aquifer, it can be seen on the cross-section (Fig. 5 \& 6).

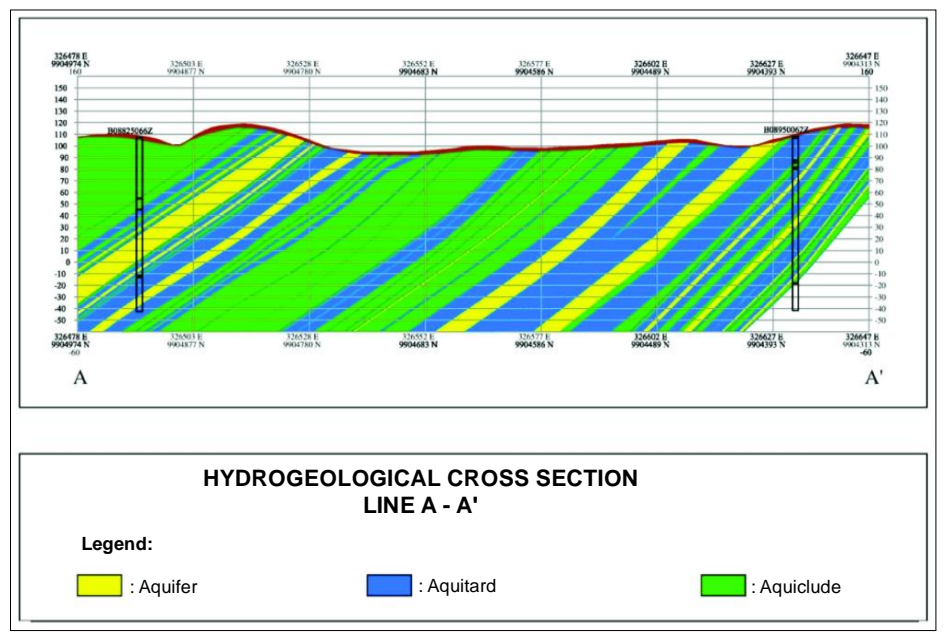

Fig 5. The location of hydrogeological cross section

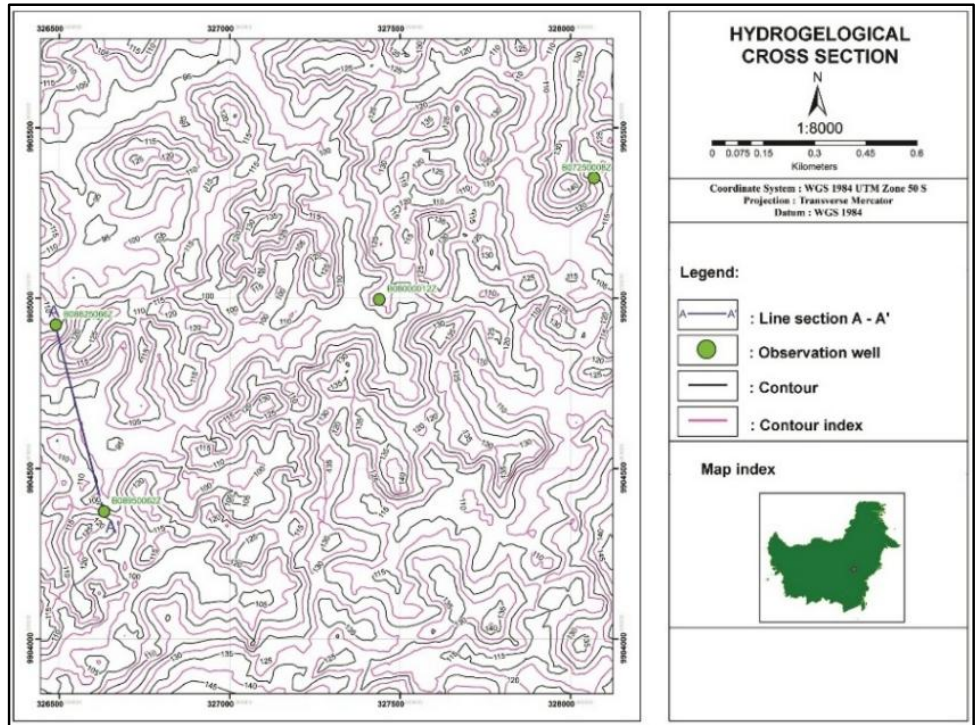

Fig 6. Hydrogeological cross section

\subsection{Rainfall Intensity}

Rainfall is a major factor affecting the research area. The amount of rainfall on the surface of the earth is expressed in water depth (usually $\mathrm{mm}$ ), which is considered to be equally distributed throughout the catchment area. Rain intensity is the amount of rainfall in units of time (Devy and Sarungallo, 2018). The average daily rainfall is the amount of rainfall in a month divided by the number of rainy days in a month. Average monthly rainfall is the amount of rainfall in one year divided by 12 . Annual rainfall is the amount of rainfall per year. Determination of rainfall intensity is done by taking data from monthly rainfall divided by the number of rainy days on average in that month. Based on the data, it can be concluded that the amount of monthly rainfall in the research area is 237.9 $\mathrm{mm} /$ month and annual is $2.854,85 \mathrm{~mm} /$ year. The amount of monthly rainfall in the study area is presented in Table 3 .

Table 3. Rainfall intensity (mm/month)

\begin{tabular}{cccccccccccccc}
\hline Year & Jan & Feb & Mar & Apr & May & Jun & Jul & Aug & Sep & Oct & Nov & Dec \\
\hline 2010 & 124.7 & 126.7 & 797.3 & 1845.3 & 230.2 & 176.6 & 109.41 & 121.6 & 76.6 & 194.3 & 350.1 & 374.1 \\
2011 & 164 & 196.2 & 278.9 & 309.1 & 186.4 & 41.2 & 175.3 & 122.7 & 98.5 & 246.6 & 165.3 & 211.3 \\
2012 & 148.2 & 161.5 & 157.2 & 163.7 & 222.6 & 320.1 & 258.7 & 144.1 & 202 & 235.1 & 184.8 & 223.9 \\
2013 & 351.6 & 232.2 & 246.3 & 192.4 & 237.1 & 68.56 & 84.6 & 14 & 177.7 & 219.2 & 231.8 & 236.6 \\
2014 & 361.2 & 202.7 & 110.2 & 44.8 & 79.4 & 764.9 & 600 & 576.8 & 657.5 & 576.1 & 977.1 & 426.8 \\
2015 & 999.7 & 1.015 .5 & 1.080 .6 & 291.1 & 315.72 & 131.95 & 139.7 & 171.33 & 176.6 & 201.4 & 226.7 & 365.5 \\
2016 & 250.2 & 79.3 & 167.17 & 210 & 225.9 & 135.2 & 47.8 & 120.9 & 58.3 & 79.9 & 143.6 & 142.9 \\
2017 & 198.6 & 38.9 & 225.4 & 336.3 & 199.4 & 98.6 & 271 & 145.4 & 94.1 & 339.6 & 304.5 & 296.5 \\
2018 & 227.8 & 206.8 & 214.6 & 206.6 & 306.5 & 184.6 & 24.4 & 97.5 & 107.7 & 69.6 & 190.6 & 110 \\
2019 & 306.8 & 220.4 & 260.4 & 339.7 & 112.3 & 213.4 & 278.5 & 132.9 & 182.6 & 181.4 & 84.6 & 138.2 \\
\hline
\end{tabular}




\subsection{Evapotranspiration}

Evapotranspiration is the process of water moving to the atmosphere by the evaporation from the soil and other surfaces and by transpiration from plants (Spitz and
Moreno, 1996). Evapotranspiration is affected by the amount of rainfall and average annual air temperature in the target area of the study. The air temperature data in the period of 2010-2019 is presented in Table 4. The result of evaporation calculation can be seen in Table 5 :

Table 4. Average air temperature in 2010-2019 (Celsius)

\begin{tabular}{llllllllllrrrrr}
\hline Years & Jan & Feb & Mar & Apr & May & Jun & Jul & Aug & Sep & Oct & Nov & Dec \\
\hline 2010 & 27.02 & 27.31 & 27.27 & 27.51 & 26.51 & 27.3 & 26.86 & 26.95 & 27.68 & 27.13 & 27.93 & 27.46 \\
2011 & 27.1 & 26.89 & 27.67 & 28.05 & 26.98 & 27.1 & 26.81 & 27.12 & 28.72 & 27.69 & 28.18 & 27.29 \\
2012 & 27.2 & 28.39 & 29.19 & 27.69 & 28.44 & 27.8 & 27.93 & 27.21 & 26.95 & 27.38 & $26 Q .681$ & 26.85 \\
2013 & 27.2 & 27.55 & 27.84 & 28.02 & 27.84 & 27.57 & 27.18 & 27.97 & 28.16 & 27.93 & 28.17 & 27.93 \\
2014 & 26.8 & 28.1 & 28.23 & 27.94 & 28.48 & 28 & 27.73 & 27.12 & 28.42 & 28.15 & 29.01 & 29.29 \\
2015 & 29.1 & 28.51 & 27.13 & 28.18 & 27.23 & 28.58 & 27.78 & 27.82 & 27.95 & 28.16 & 28.64 & 29.01 \\
2016 & 28.17 & 29.33 & 29.75 & 27.12 & 28.49 & 28.25 & 28.58 & 27.91 & 28.92 & 29.53 & 28.78 & 28.51 \\
2017 & 27.26 & 27.17 & 28.31 & 28.72 & 28.65 & 28.3 & 28.55 & 27.18 & 30.72 & 31.15 & 30.14 & 30.21 \\
2018 & 30.2 & 20.6 & 30.11 & 29.82 & 30.5 & 29.09 & 29.3 & 29.22 & 28.94 & 29.14 & 28.961 & 29.64 \\
2019 & 28.51 & 28.1 & 28.49 & 28.57 & 29.18 & 28.86 & 28.3 & 28.821 & 28.1 & 28.19 & 28.12 & 28.67 \\
\hline
\end{tabular}

Source: https://www7.ncdc.noaa.gov/CD0

Table 5. Evapotranspiration calculation

\begin{tabular}{lll}
\hline Rainfall (mm/year) & $(\mathrm{P})$ & $2.854,85$ \\
\hline Average air temperature $\left({ }^{\circ} \mathrm{C}\right)$ & $(\mathrm{Tm})$ & 28,13 \\
Evapotranspiration $(\mathrm{mm} /$ year $)$ & $(\mathrm{Evp})$ & $1.731,261$ \\
\hline
\end{tabular}

\subsection{Surface Run-off}

Surface water is all water present on the ground surface while the surface water that flows is called the surface stream. The most important part of the surface runoff is the peak flow, the time peak flow is reached, volume, and surface runoff. The parameters affecting the amount of

Table 6. Surface run-off calculation

\begin{tabular}{lll}
\hline Rainfall (mm/year) & $(\mathrm{P})$ & $2.854,85$ \\
\hline Area of watershed (ha) & (A) & 890,3 \\
Run-off (mm/year) & (Ro) & 1077,98 \\
\hline
\end{tabular}

\subsection{Groundwater Recharge}

In the hydrogeology system, water always undergoes a recycling process called the hydrogeological cycle. In that cycle, the water will always go through the aquifer system called the recharge process, that is, the addition of water into the aquifer zone. The amount of water added to the surface runoff distribution are rainfall, as well as the maximum of potential retention obtained from the calculation based on the parameter of curve number (CN) in the land use area of the area of study (Devy and Sarungallo, 2018). The surface runoff calculation results can be seen in Table 6 . Table 7. Groundwater recharge calculation

\begin{tabular}{lll}
\hline Rainfall (mm/year) & (P) & $2,854.85$ \\
\hline Evapotranspiration (mm/year) & (Evp) & $1,731.261$ \\
Surface run-off (mm/year) & (Ro) & $1,077.98$ \\
Groundwater recharge (mm/year) & (U) & 45.61 \\
\hline
\end{tabular}

\subsection{Natural Groundwater Modelling}

Groundwater modelling is used to simulate and predict the condition of the aquifer. This modelling is able to present groundwater conditions, such as the pattern of groundwater flow and groundwater levels (Boonstra and

Table 8. Input data for groundwater modelling

\begin{tabular}{lll}
\hline \multirow{2}{*}{ Hydraulic conductivity (m/s) } & K1 & $1.10 \times 10^{-5}$ \\
\cline { 2 - 3 } & K2 & $1.11 \times 10^{-4}$ \\
\hline Constant head (m) & $170-169$ & \\
River (m) & $132-130$ & \\
Recharge (mm/year) & 45.61 & \\
\hline
\end{tabular}

The results of the modelling by Visual Modflow shows the value of the hydraulic head of natural conditions in the aquifer zone can be calculated based on the number of hydrological parameters such as rainfall, evapotranspiration and surface run-off (Devy and Sarungallo, 2018). Groundwater recharge calculation results can be seen in Table 7 .

Ridder, 1981). The input of groundwater modelling data is groundwater recharge, hydraulic conductivity of the aquifers, constant head value, and river water level. Input data from calculations and research in the study area can be seen in Table 8

study area with a maximum height of $+108 \mathrm{~m}$ ASL and a minimum of $+76 \mathrm{~m}$ ASL. The distribution of the average of 
the hydraulic head from high elevation in the south to the lowest elevation in the east on the Biangan River. The equipotential hydraulic head distribution in the aquifer illustrates that the hydraulic head equipotential is getting lower and denser when it reaches the river system of Biangan. The decrease of the contour densities causes

\subsection{Lithology Conditions of the Mine Pit Area}

The outcome data of the drilling demonstrate that sandstone, siltstone, claystone, coal and carbonaceous clay layers are the rocks forming the slopes in the open-pit groundwater in the aquifer to flow into the rivers with low hydraulic heads. That is why it can be concluded that groundwater fills river water (effluent). Description of groundwater flow patterns and potential head in the study area can be seen in Fig. 7.

mining. A detailed lithological cross-section is shown in Fig. 8. Meanwhile, the cross-section of the rock layers (lithology) in the mine pit can be seen in Fig. 9.

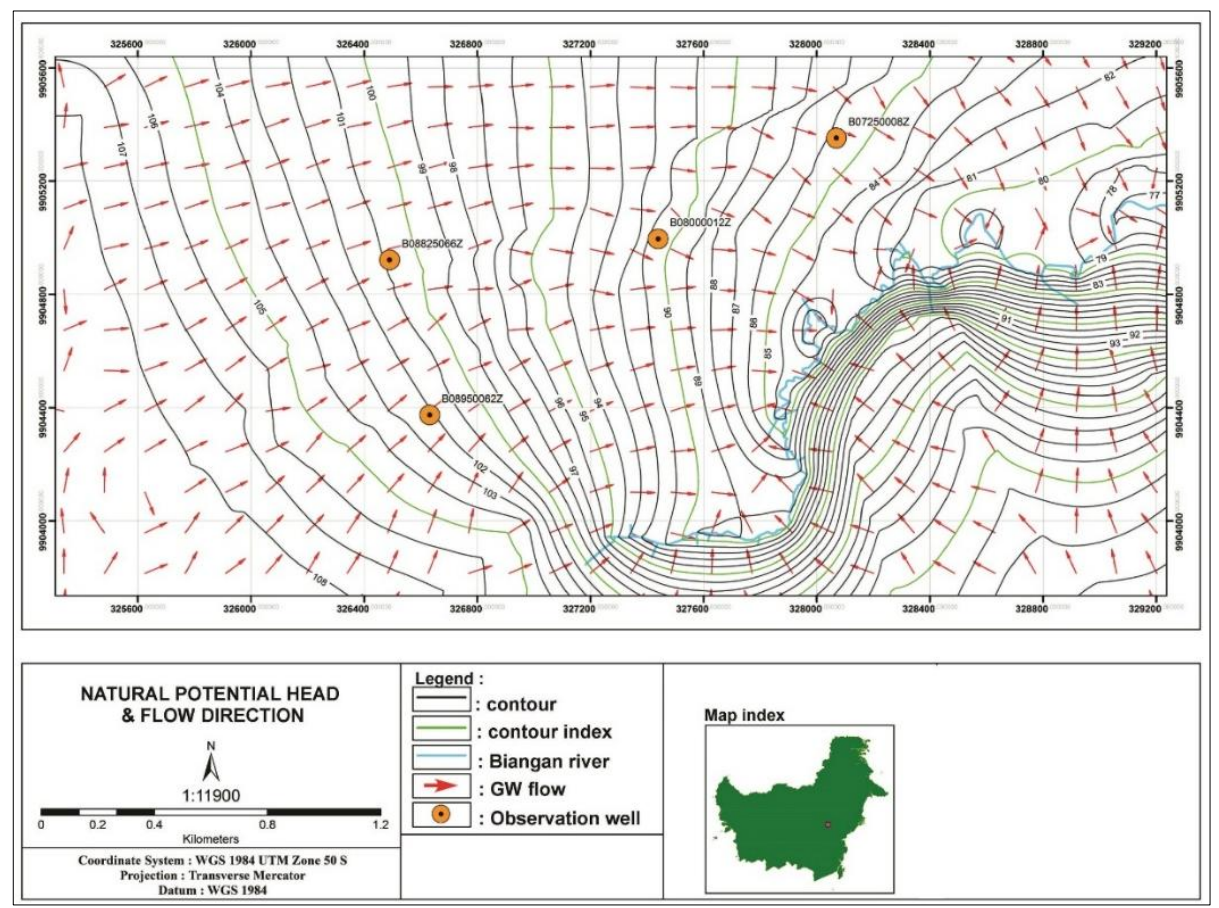

Fig 7. Natural potential head and groundwater flow direction

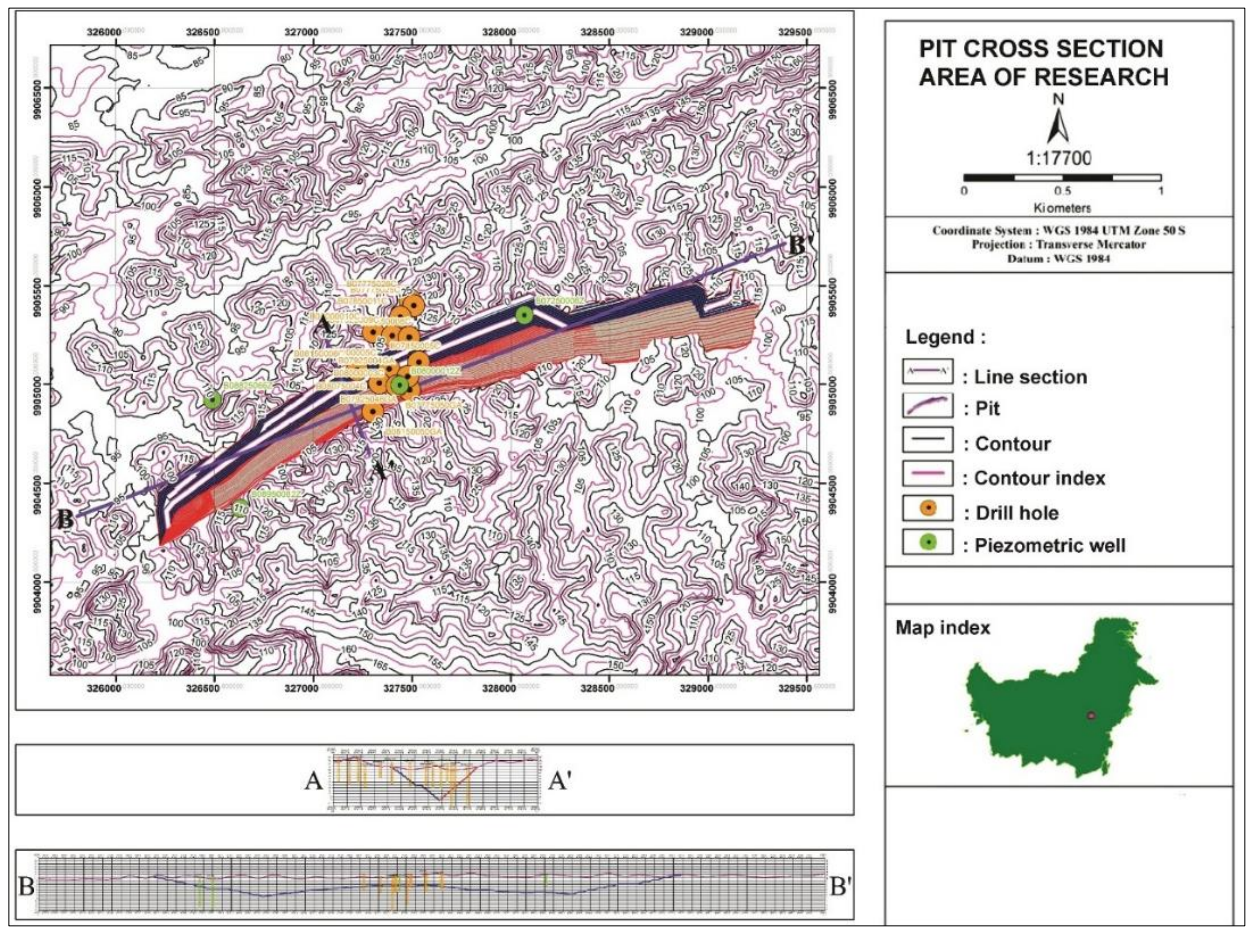

Fig 8. Mining pit cross section 


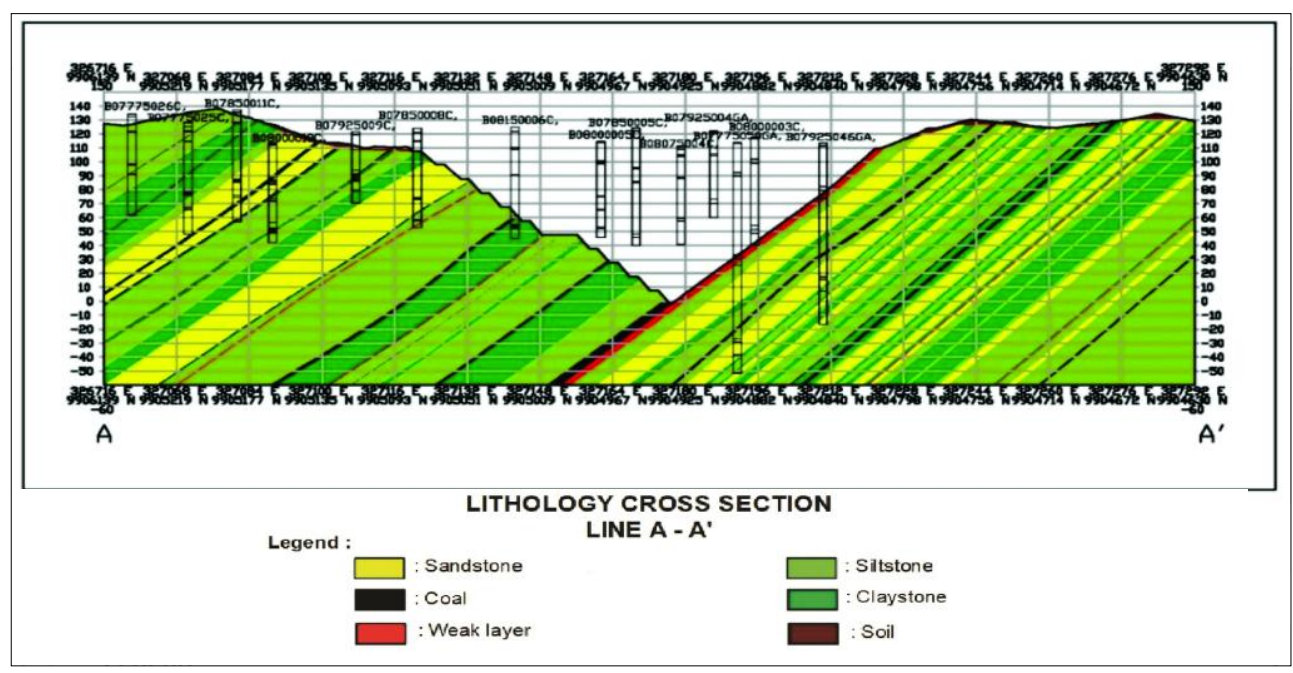

Fig 9. Lithology and pit cross section

\subsection{Mechanical and Physical Properties Parameters}

Mechanical properties test values obtained through the laboratory tests include the value of cohesion (kappa), angle of repose $\left({ }^{\circ}\right)$, while the modulus young value and Poisson ratio based on the standards proposed by

Alfreds R.J. (Alfreds R. Jumikis, 1983). The mechanical property values are presented in Table 9 and physical properties in Table 10 as follows:

Table 9. Mechanical properties

\begin{tabular}{|c|c|c|c|c|c|c|c|}
\hline \multirow{2}{*}{ No } & \multirow{2}{*}{ Material } & \multicolumn{2}{|c|}{$\begin{array}{l}\text { Cohesion } \\
(\mathrm{kPa})\end{array}$} & \multicolumn{2}{|c|}{ angle of repose $\left(^{\circ}\right)$} & \multirow{2}{*}{$\begin{array}{l}\text { Modulus Young } \\
(\mathrm{kPa})^{*}\end{array}$} & \multirow{2}{*}{$\begin{array}{l}\text { Poisson } \\
\text { Ratio* }\end{array}$} \\
\hline & & Peak & Residue & Peak & Residue & & \\
\hline 1 & Coal & 150 & 150 & 36 & 36 & 500000 & 0.3 \\
\hline 2 & Weak Layer & 3 & 3 & 18.05 & 18.05 & 500000 & 0.3 \\
\hline 3 & Topsoil & 10 & 10 & 34 & 18 & 500000 & 0.3 \\
\hline 4 & 32 Sandstone & 312.05 & 74.155 & 12.81 & 10.165 & 44600000 & 0.17 \\
\hline 5 & 32 Siltstone & 152.11 & 14.776 & 4.45 & 4.13 & 16650000 & 0.265 \\
\hline 6 & 32 Claystone & 141.78 & 31.225 & 9.6 & 7.63 & 16650000 & 0.265 \\
\hline 7 & 43 Sandstone & 124.38 & 40.26 & 8.46 & 6.458 & 44600000 & 0.17 \\
\hline 8 & 43 Siltstone & 124 & 11.2 & 8.31 & 7.407 & 16650000 & 0.265 \\
\hline 9 & 43 Claystone & 117 & 14.6 & 15.28 & 11.25 & 16650000 & 0.265 \\
\hline 10 & 54 Sandstone & 362.4 & 9.5 & 30.09 & 18.72 & 44600000 & 0.17 \\
\hline
\end{tabular}

$\left(^{*}\right)$ Source: (Alfreds R. Jumikis, 1983)

Table 10. Material weight value

\begin{tabular}{lll}
\hline No & Material & Weight value $(\mathrm{kN} / \mathrm{m} 3)$ \\
\hline 1 & Coal & 13 \\
2 & Weak Layer & 19 \\
3 & Topsoil & 18 \\
4 & 32 Sandstone & 23.31 \\
5 & 32 Siltstone & 23.31 \\
6 & 32 Claystone & 23.31 \\
7 & 43 Sandstone & 23.47 \\
8 & 43 Siltstone & 23.47 \\
9 & 43 Claystone & 23.47 \\
10 & 54 Sandstone & 23.08 \\
\hline
\end{tabular}

\subsection{Groundwater Condition of the Slope}

Groundwater in the study area affects the stability of the slope at the mine pit, that is why a cross-section of the groundwater model is required which is useful for knowing groundwater flow pattern details. The cross-section line is located at $327057.23 \mathrm{mE}-327288.50 \mathrm{mE}, 9905246.24 \mathrm{mN}$ - $9904640.28 \mathrm{mN}$ (Fig. 10).

\subsubsection{Pre-Mining Groundwater conditions}

The results of groundwater modelling before mining activity are illustrated in the A - A' section (Fig. 10). Based on the section, the groundwater level is found on the west side of the cross-section as high as +89.9 meters above sea level and the east side of the cross-section has groundwater level as high as +87.3 meters above sea level. In addition, in cross-section A - $\mathrm{A}^{\prime}$ it is known that natural condition groundwater has decreased. This condition can be seen from cross-section where groundwater level which has decreased on the east side and the groundwater flows from 
west to east. Cross-section A - A' (Fig. 10), which refers to Fig. 7, showing that the pattern of groundwater flow of the natural conditions flows towards the Biangan river located in the eastern area.

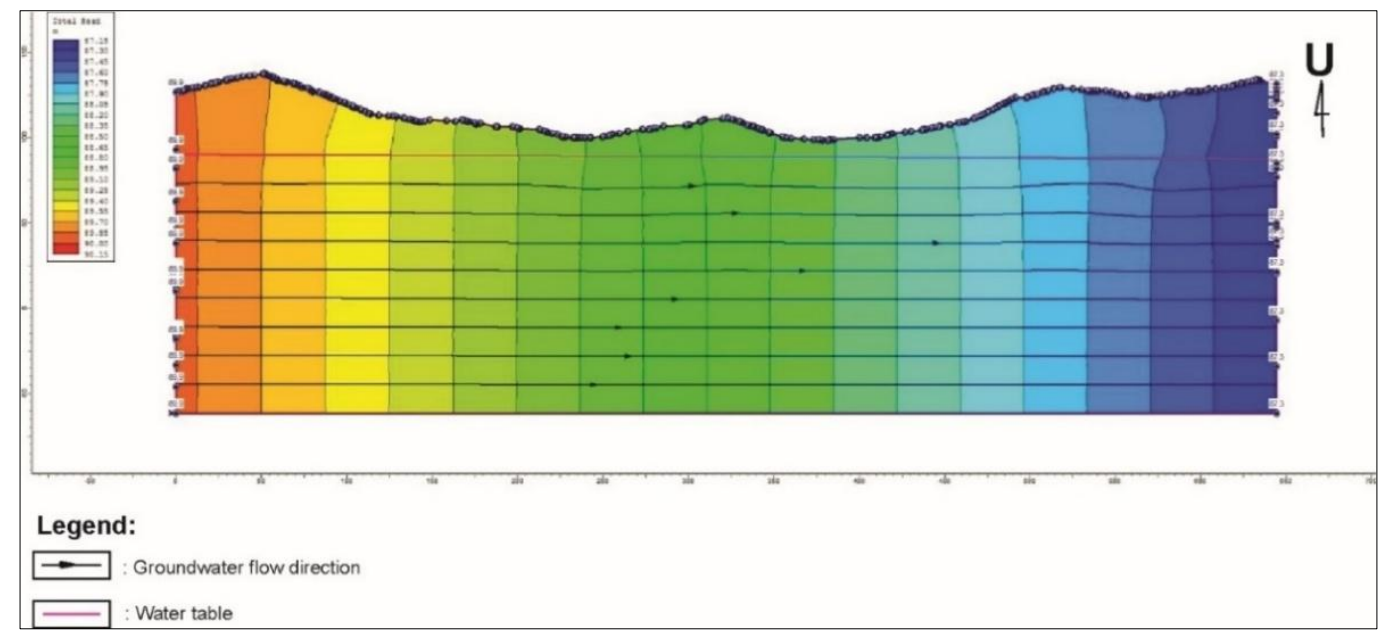

Fig 10. Groundwater cross section in pre-mining (natural condition)

\subsubsection{Active Mining Groundwater Conditions}

There is a change in groundwater flow patterns in active mining (Fig. 11). This difference is due to changes in land use (mining) and hydrostratigraphy where the mine pit is reaching a depth of -111.43 meters passing through the aquifer resulting the decrease of hydraulic pressure along with the influence of gravitational force causing a high groundwater flow

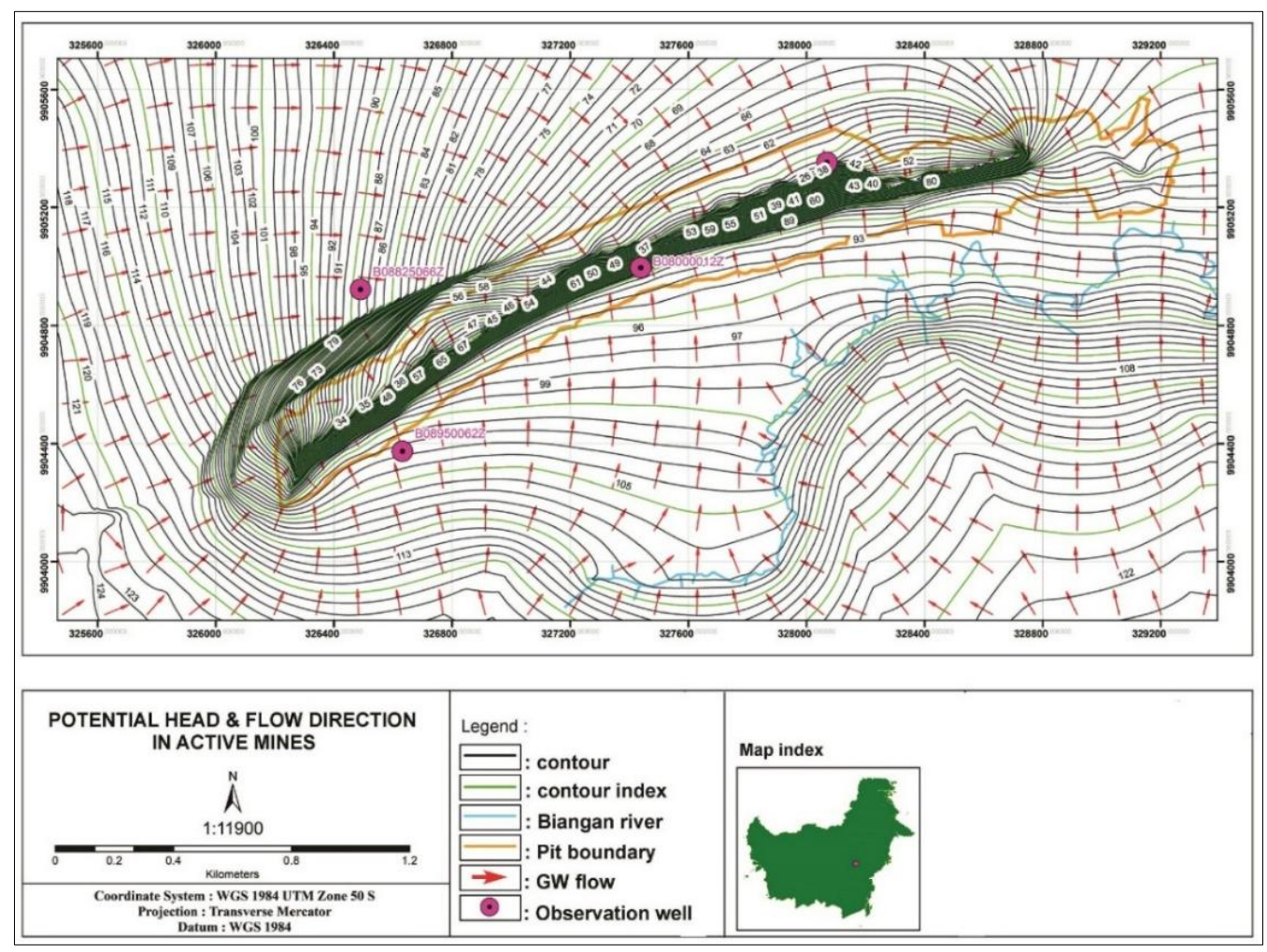

Fig 11. Potential head and groundwater flow direction in active mining

A more detailed analysis has been carried out further using the Phase 2 application, it can be seen that in the crosssection A - A' (Fig. 12), the groundwater level is found on the west side of the cross-section as high as +89.9 meters above sea level $+87.3 \mathrm{~m}$ ASL on the east side. The height is used as a boundary condition to determine groundwater conditions after a pit. In cross-section A - A 'in Fig. 12, it can be seen that groundwater in active mining conditions has decreased towards the pit basin, this proofs that water will flow from a high elevation to a lower elevation. 


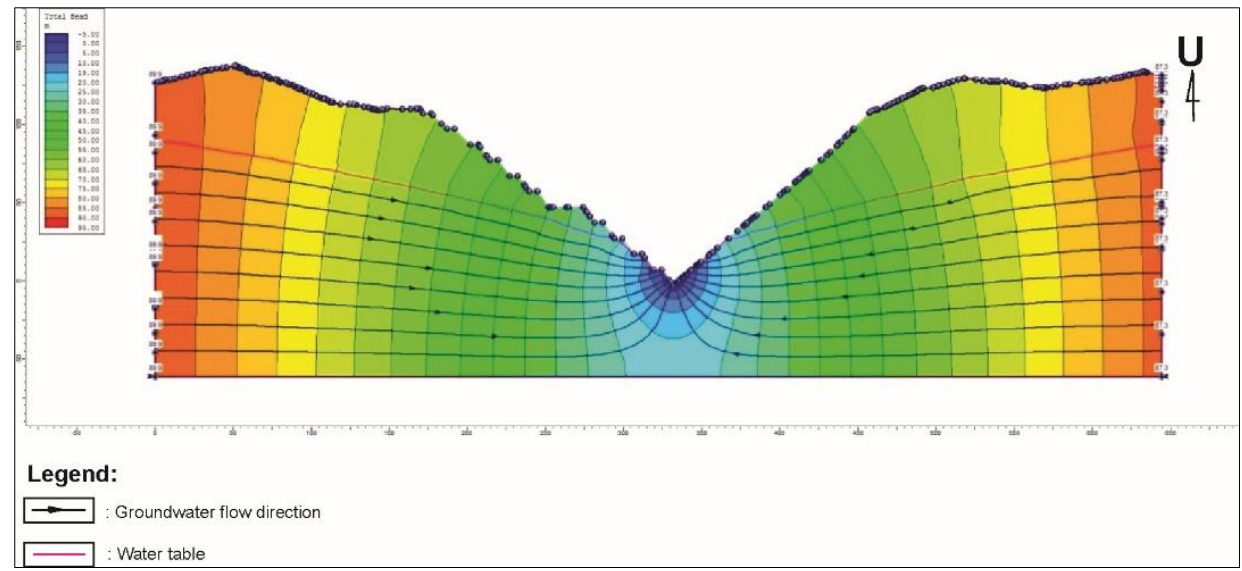

Fig 12. Groundwater cross section in active mining

\subsection{Slope Stability Analysis}

Slope stability analysis is carried out on the high wall and low wall (Arif, 2016). There are two coal seams named seam A1 and seam A2 in the pit area which have a thickness of 3 and 4.40 meters respectively. Mining activity in this area is carried out from east to west at the elevations up to $-3 \mathrm{~m}$ ASL. Location is determined by drawing a cross-section of the pit area of the mine to be analyzed in the direction of the strike. The location and cross-section can be seen in Fig. 12. The location of cross-section drawing in Fig. 12 and Fig. 13 are at the same coordinates, which are located at 327057.23 $\mathrm{mE}-327288.50 \mathrm{mE}, 9905246.24 \mathrm{mN}-9904640.28 \mathrm{mN}$.

\subsubsection{Low wall pit slopes analysis}

Overall slope stability analysis is carried out on the low wall. Low wall pit slope has a slope angle of $41^{\circ}$ with the slope follows the dip angle of rock layers. The low wall is on the elevation of +108.625 meters above sea level. Mining activity will be done up to an elevation of -3 meters above sea level with the depth of -111.625 meters of the open-pit mining.
The low wall analysis is determined by groundwater conditions as a factor affecting the stability of the low wall. Groundwater level on the low wall (Fig. 13) on the east side of the cross-section is as high as +87.3 m ASL. The results of the calculation of the stability of the low wall (Fig. 13) presenting a Critical SRF value of 0.65 with a total displacement of 0.019 meters. This indicates that the driving force exceeds the restraining force causing the collapse of this slope. Maximum shear strains of low wall form a circular behind a low wall, these slopes form folds on the toe of the low wall which the mechanism is caused by the bulking process which is a force working perpendicularly to the plane of the surface layer. This is caused by groundwater adding weight to the slope which increases the material thrust force. After the bulking process the translational slides occur on the slope in the form of a planar plane. This slip occurs due to the weak layer above the strong material or material that has a higher rock strength value than the weak layer. Displacement on the slope can in Fig. 14.

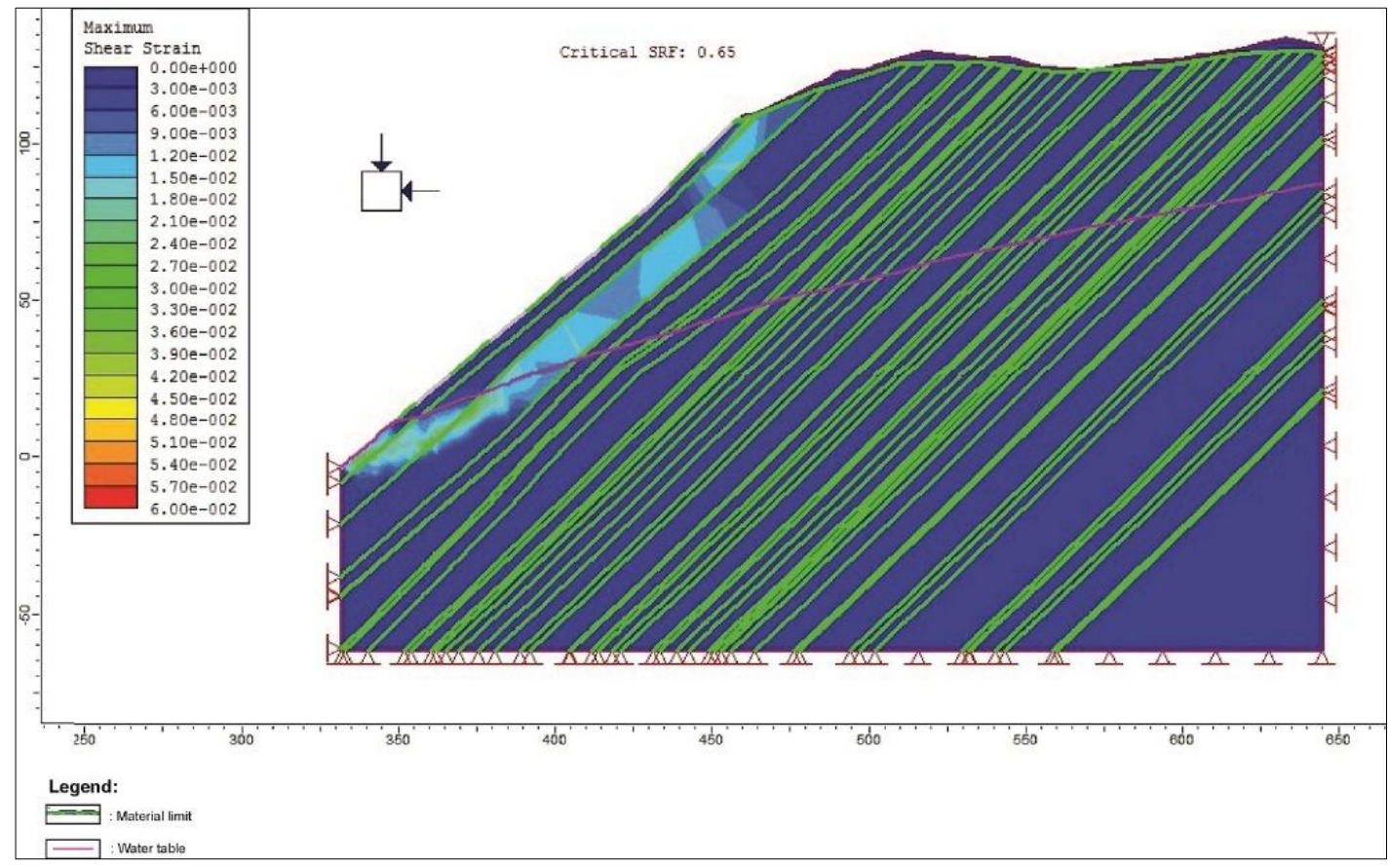

Fig 13. Results of low wall pit slope analysis affected by groundwater 


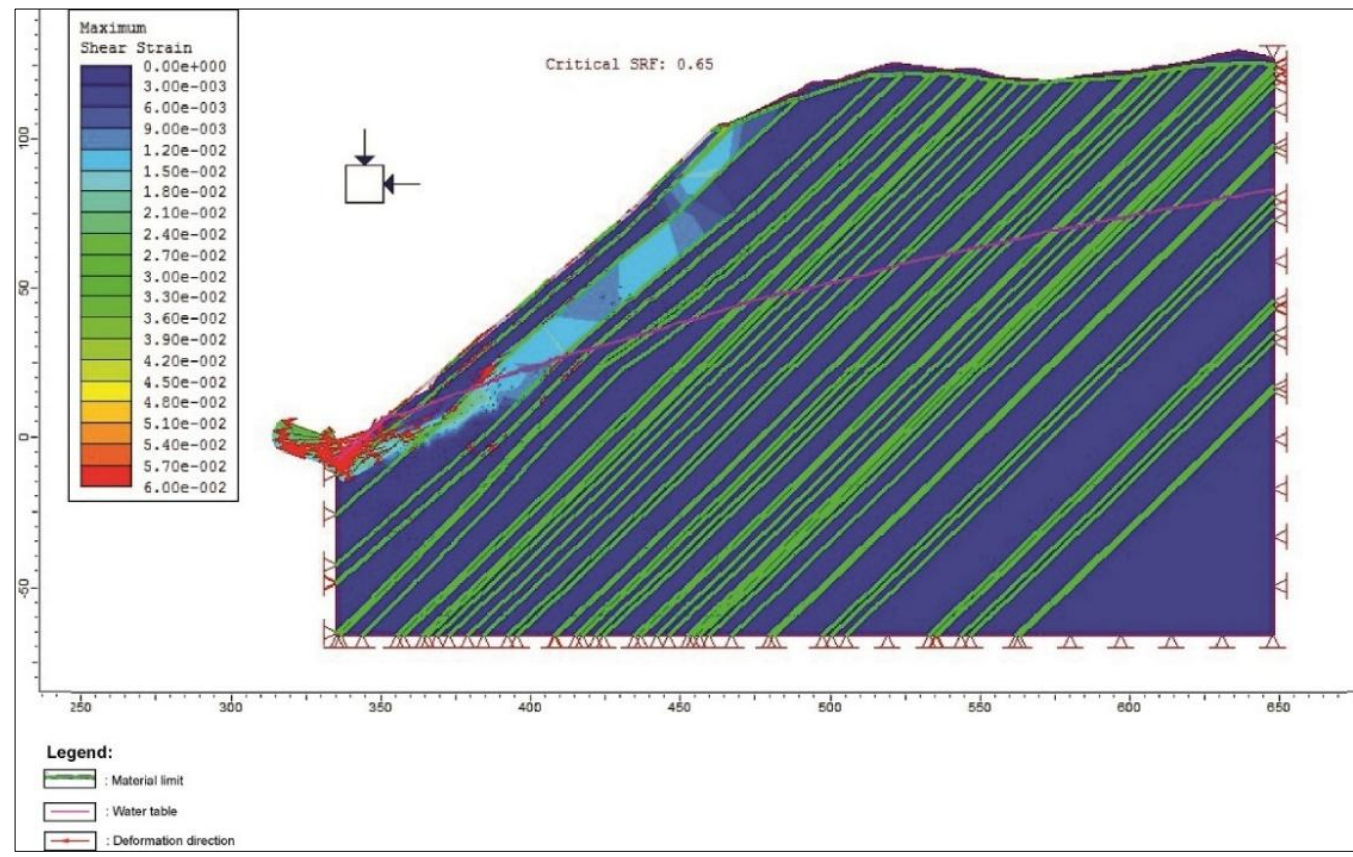

Fig 14. Displacement on the low wall pit slope

Based on the Infinite element calculations the slope is considered to have collapsed if the iteration calculation fails to converge. Non-convergent iteration indicates that no stress distribution can be achieved to meet Mohr-Coloumb criteria. Non-convergent iteration is followed by an increase in the displacement of the force which experiences a large jump when the slope collapses (Hustrulid et al., 2006).

The maximum of total displacement value of the low wall on the SRF prior to the collapse is presented in Table 11 with the displacement graph in Fig. 15.

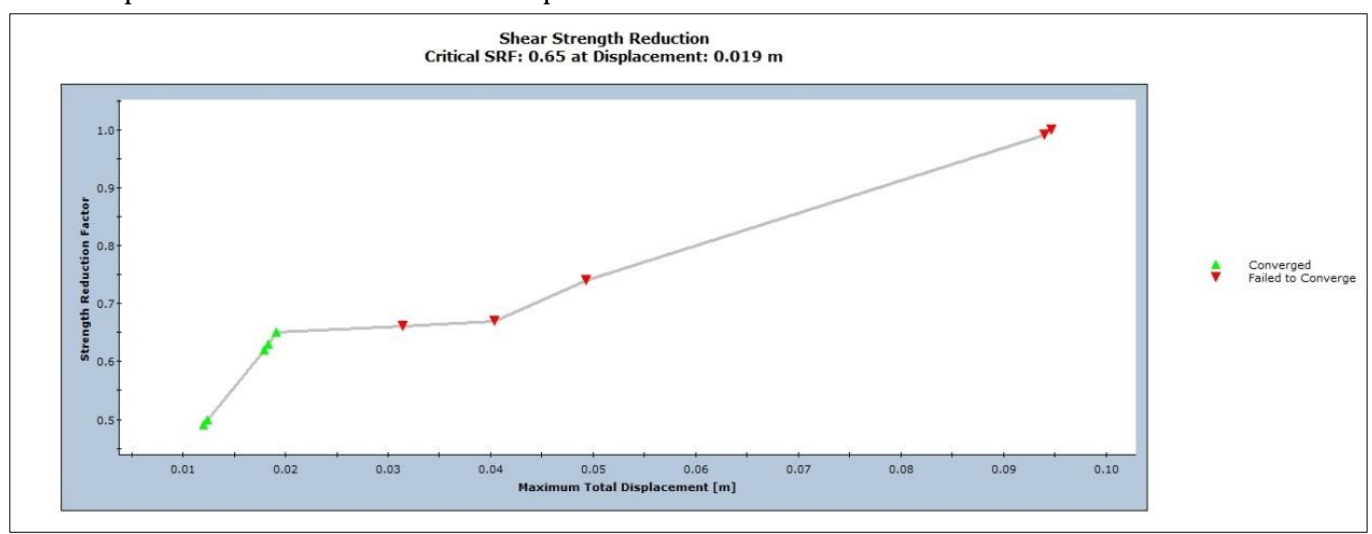

Fig 15. Graph of SRF critical relationship on low wall pit slopes and groundwater redesign

Table 11. Displacement in low wall pit affected by groundwater

\begin{tabular}{ll}
\hline Maximum Total Displacement $(\mathrm{m})$ & Critical Strength Reduction Factor \\
\hline 0.0120359 & 0.49 \\
0.012374 & 0.5 \\
0.0179814 & 0.62 \\
0.0183113 & 0.63 \\
0.0191521 & $\mathbf{0 . 6 5}$ \\
0.0314913 & $0.66^{*}$ \\
0.0404371 & $0.67^{*}$ \\
0.0493267 & $0.74^{*}$ \\
0.0939805 & $0.99^{*}$ \\
0.0946841 & $1^{*}$ \\
\hline
\end{tabular}

$\left.{ }^{*}\right)$ Iteration Non - convergent

\section{High wall pit slope analysis}

Overall slope stability analysis is carried out on the high wall. The high wall has an overall slope angle of $35^{\circ}$ with the geometry of the slope as follows: The height, berm width and ramp width of the single-slope is $10 \mathrm{~m}, 5 \mathrm{~m}$ and $22 \mathrm{me}$ respectively and the angle of a single slope is $45^{\circ}-53^{\circ}$. High wall is at the elevation of $+109.743 \mathrm{~m}$ ASL. Mining activity will be done up to $-3 \mathrm{~m}$ ASL and to the depths of -112.743 meters. 
The high wall slope stability analysis is influenced by groundwater. Groundwater level on the high wall, based on Fig. 16, on the western side of the cross section, has groundwater level as high as +89.9 meters above sea level. The results of the calculation of the stability of the high wall using the finite element method (Fig. 16) showing a Critical SRF value of 1.4 with a total displacement of 0.002 meters.
This indicates that the holding force exceeds the driving force making the high wall at the Pit is in a safe condition. There is a slight movement on the shear strain of the high wall maximum on the toe slope. The high wall has the opposite bedding plane to the slope so that when a landslide occurs on the toe slope the high wall is safe. Displacement or displacement on the slope can be seen in Fig. 17.

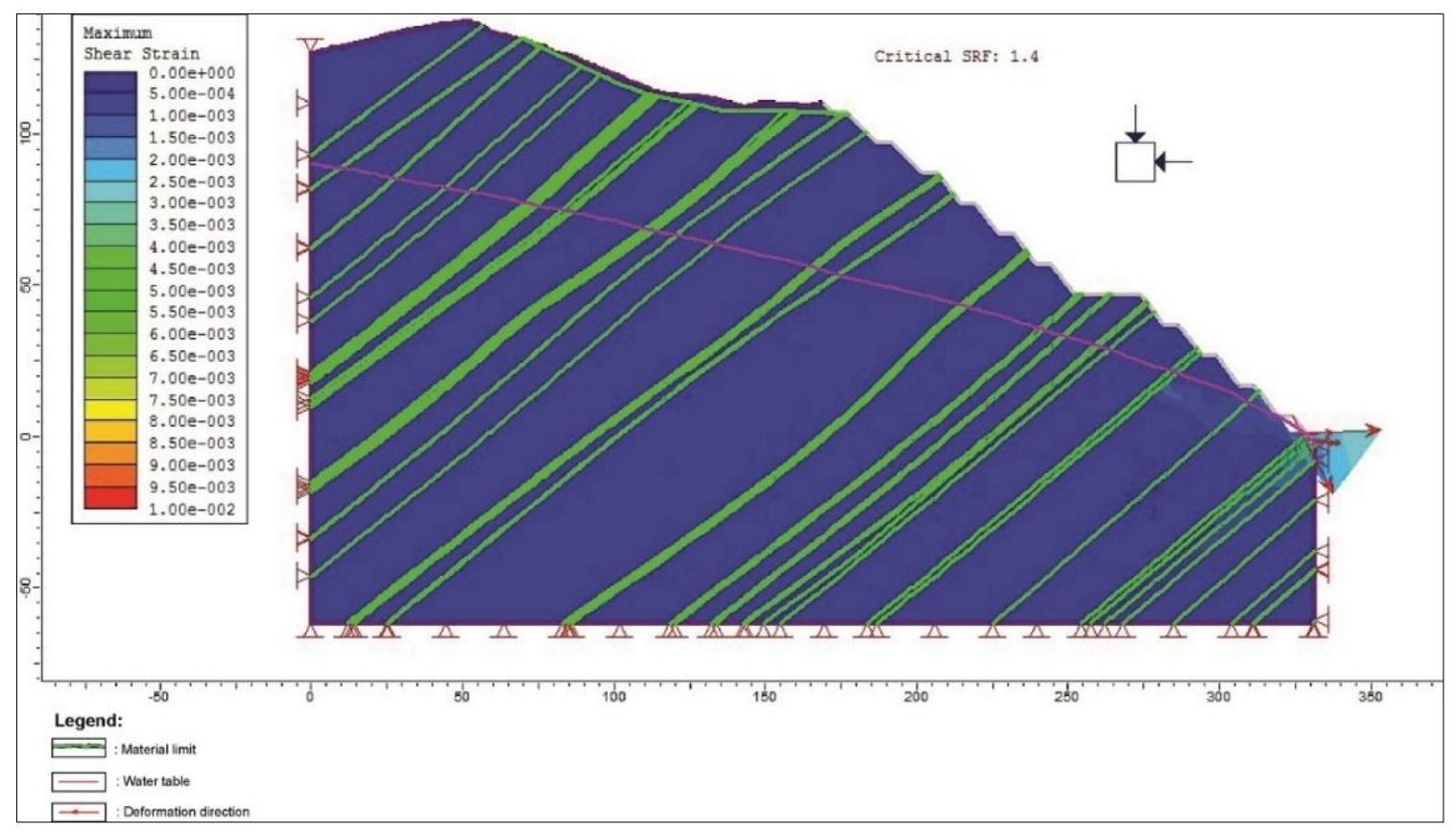

Fig 17. Displacement on the high wall pit slope

In finite element calculations, the slope is considered to collapse if the iteration calculation fails to converge or nonconvergent. Non-convergent iteration indicates that no stress distribution can be achieved to meet Mohr-Coulomb criteria. Non-convergent iteration is followed by an increase in displacement that experiences a large jump when the slope collapses. The maximum total displacement value of the high wall at a particular SRF before the collapse occurs is presented in Table 12 and the displacement graph in Fig. 18.

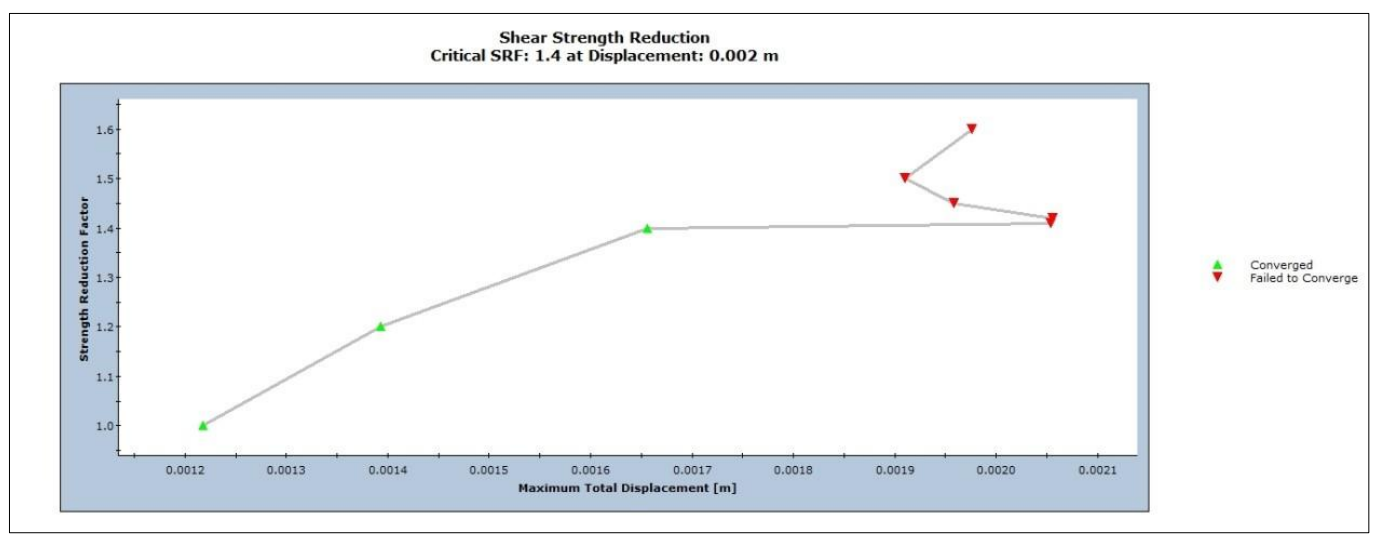

Fig 18. Graph of SRF critical relationship on high wall pit slopes and groundwater redesign

Table 12. Displacement on the high wall pit which is affected by groundwater

\begin{tabular}{ll}
\hline Maximum Total Displacement $(\mathrm{m})$ & Critical Strength Reduction Factor \\
\hline 0.00121806 & 1 \\
0.00139348 & 1.2 \\
0.0016564 & $\mathbf{1 . 4 0}$ \\
0.00205425 & $1.41^{*}$ \\
0.00205577 & $1.42^{*}$ \\
0.00195831 & $1.45^{*}$ \\
0.00191046 & $1.5^{*}$ \\
0.00197568 & $1.6^{*}$ \\
\hline
\end{tabular}

(*) Iteration Non - convergent 


\section{Low wall pit redesign}

Based on the analysis results the high wall of the Pit has a Critical SRF value or a Safety Factor that exceeds the Critical SRF value or the optimum Safety Factor that is equal to 1.4. Therefore, it is not needed to redesign the high wall. Meanwhile, the low wall Pit slope has a Critical SRF or a Safety Factor that is less than the optimum Critical SRF or a Safety Factor which is equal to 0.65 . This value is less than 1.3 hence, it is necessary to redesign the slope of the low wall pit in order to get a Critical SRF value or a safety factor value $\geq 1.3$. There are 2 factors causing the Critical SRF value on low wall $\leq 1.3$ such as the presence of weak layer groundwater on the low wall. Therefore, it is recommended to do the excavation until the weak layer behind the A2 seam. Furthermore, for handling groundwater, it is necessary to pump in order to reduce the saturation level on the slope to decrease the groundwater level. Groundwater pumping is performed until the groundwater level is at least 40 meters from the initial level.

Based on the recommendations given, the results show that the low wall has increased the Critical SRF value to 7.79 followed by an increase in the total displacement value on the low wall to 0.02 meters. The results of the analysis of the redesigned low wall which increased in the SRF Critical value to 7.79 (Fig. 19) and displacement of this slope can be seen in Fig. 20. The maximum of total displacement value of the high wall at a particular SRF before the collapse occurs is presented in Table 13 with the displacement graph in Fig. 21.

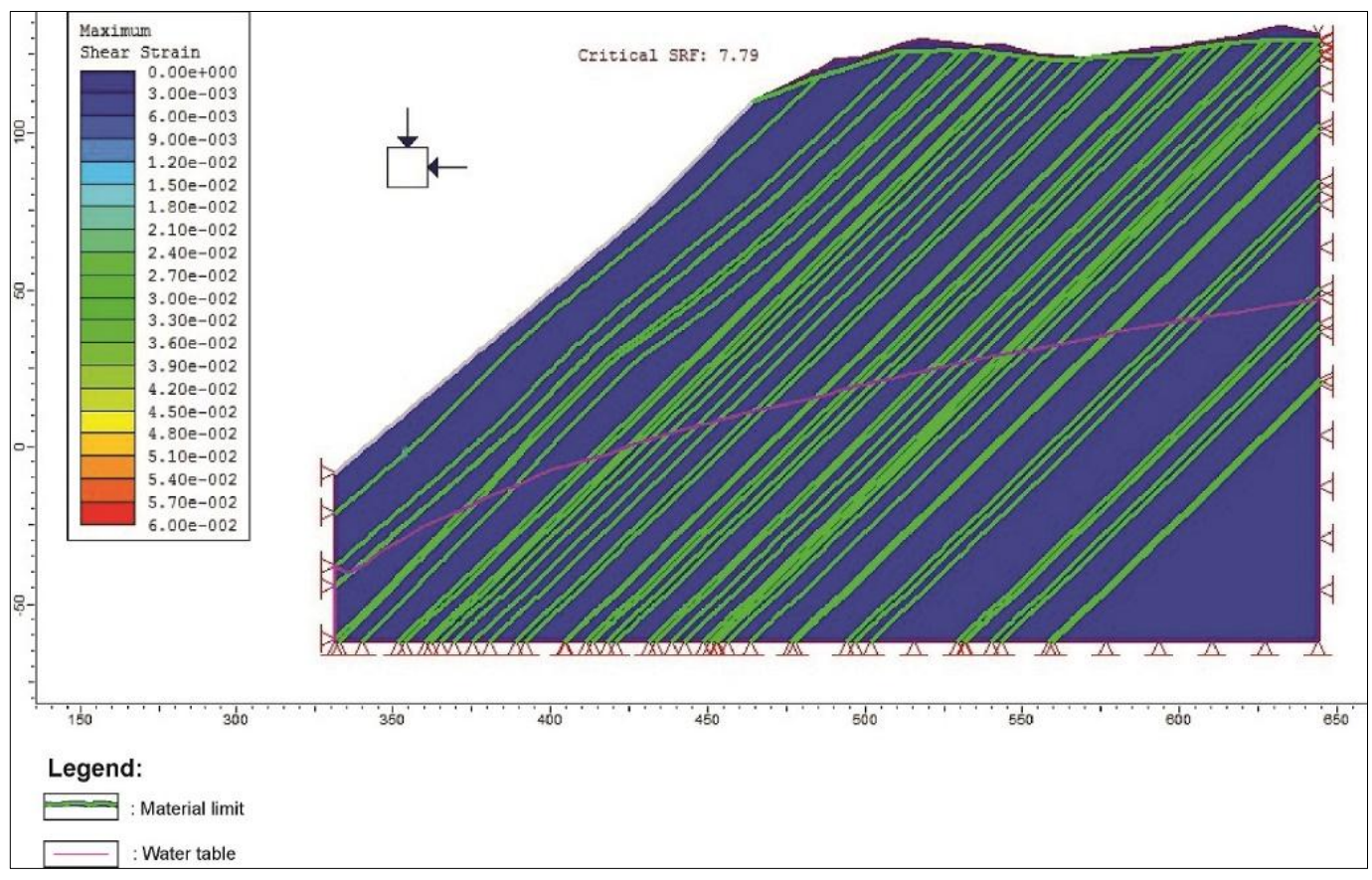

Fig 19. Results of analysis of low wall pit slopes and groundwater redesign

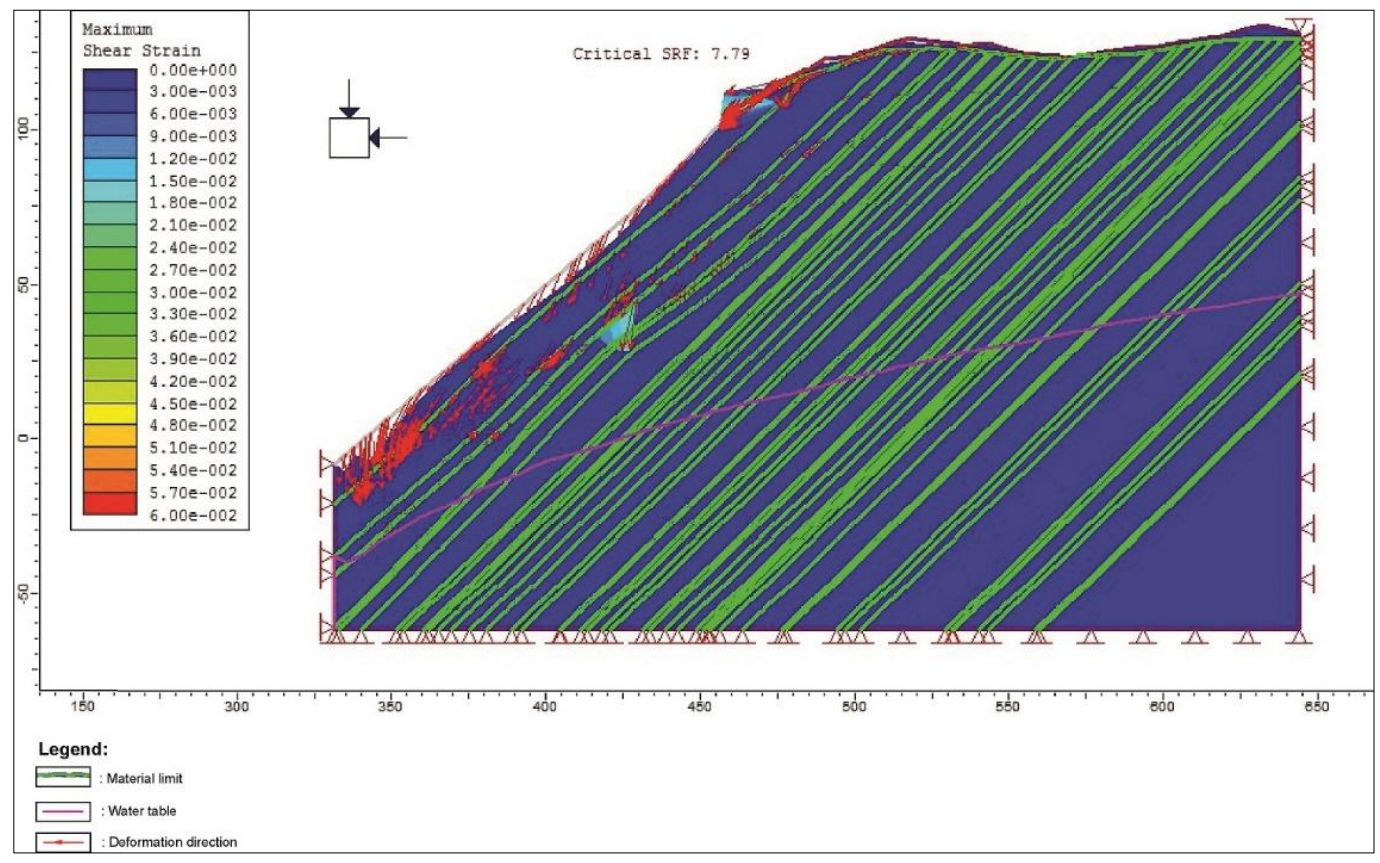

Fig 20. Displacement on low wall pit slopes after redesign 


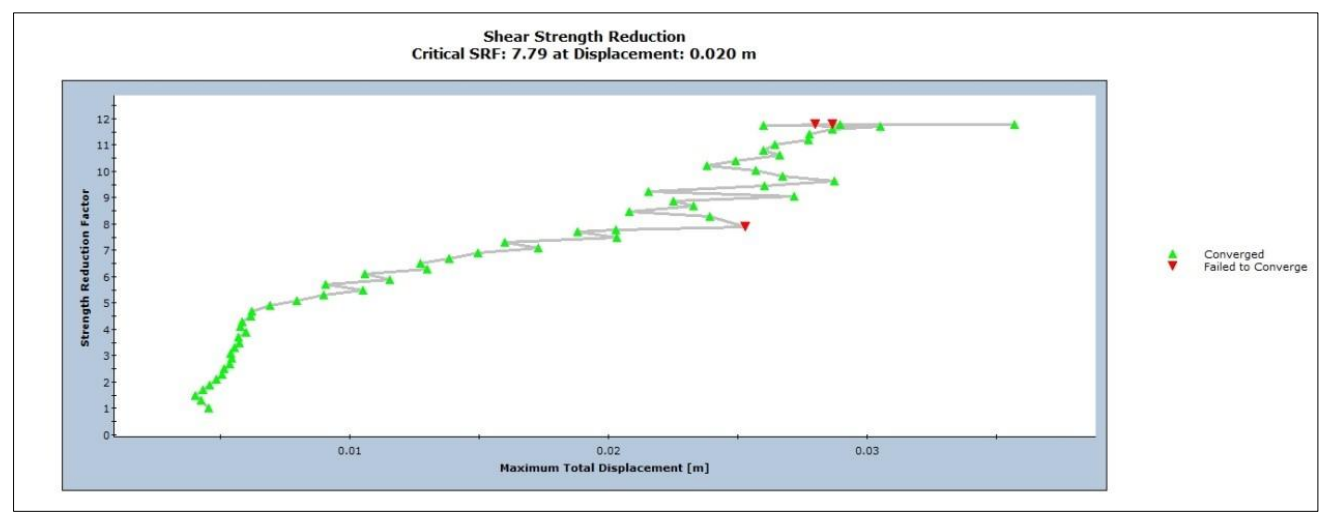

Fig 21. Graph of SRF Critical relationship on low wall pit slopes and groundwater redesign

Table 13. Displacement on the low wall pit affected by groundwater after redesign

\begin{tabular}{llll}
\hline $\begin{array}{l}\text { Maximum Total Displacement } \\
(\mathrm{m})\end{array}$ & $\begin{array}{l}\text { Critical Strength Reduction } \\
\text { Factor }\end{array}$ & $\begin{array}{l}\text { Maximum Total Displacement } \\
(\mathrm{m})\end{array}$ & $\begin{array}{l}\text { Critical Strength Reduction } \\
\text { Factor }\end{array}$ \\
\hline 0.00457508 & 1 & 0.0173016 & 7.09 \\
0.00427753 & 1.3 & 0.0159921 & 7.29 \\
0.00405801 & 1.5 & 0.0203467 & 7.49 \\
0.00433983 & 1.7 & 0.0188278 & 7.69 \\
0.00460068 & 1.9 & 0.0203083 & 7.79 \\
0.00485121 & 2.1 & 0.0252968 & $7.89^{*}$ \\
0.00507068 & 2.3 & 0.0239304 & 8.28 \\
0.00516973 & 2.5 & 0.0207948 & 8.47 \\
0.00537788 & 2.7 & 0.0233008 & 8.67 \\
0.00544767 & 2.9 & 0.022507 & 8.86 \\
0.0054261 & 3.1 & 0.027177 & 9.05 \\
0.00554496 & 3.3 & 0.0215377 & 9.25 \\
0.00575701 & 3.5 & 0.0260182 & 9.44 \\
0.00570309 & 3.7 & 0.0287324 & 9.63 \\
0.00601822 & 3.9 & 0.0267267 & 9.83 \\
0.00579475 & 4.09 & 0.0256855 & 10.02 \\
0.00585146 & 4.29 & 0.0238096 & 10.21 \\
0.00617358 & 0.0249188 & 10.41 \\
0.0062306 & 4.49 & 0.0266089 & 10.61 \\
0.00691964 & 4.69 & 0.0259937 & 10.8 \\
0.0079723 & 0.026447 & 11 \\
0.00898518 & 5.09 & 0.0277167 & 11.2 \\
0.0105124 & 5.29 & 0.0277605 & 11.4 \\
0.00908337 & 5.49 & 0.0286466 & 11.6 \\
0.011568 & 5.69 & 0.0305125 & 11.69 \\
0.0105998 & 5.89 & 0.0259935 & 11.74 \\
0.0129841 & 6.09 & 0.0289402 & 11.76 \\
0.012736 & 6.29 & 0.0356757 & 11.77 \\
0.0138695 & 6.49 & 0.0280028 & $11.78^{*}$ \\
0.0149628 & 6.69 & 0.0286418 & $11.79^{*}$ \\
\hline
\end{tabular}

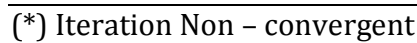

\subsection{Effect of Groundwater on Slopes}

Groundwater is one of the factors that influence the stability of the slope which results in the critical value of $\mathrm{SRF}$ on the slope that can be proven through the results of the analysis on the low wall. Groundwater on the low wall will increase the weight of the slope which will increase the material thrust force and reduce the shear strength of the material on the slope that prevents landslides (Wyllie and Mah, 2004). In addition, there is a reduction in rock material strength and weak layer factors on the low wall surface, dropping the rock mass which functions as a water seepage path. These cause landslide on the material which is below the groundwater level followed by the material above the groundwater afterwards which results in bulking. The occurrence of landslides on the material slopes which are under groundwater also occurs on high walls, but this can be overcome because the high wall has bedding planes that are opposite to the slope direction so that the high walls are in a safe condition with a Critical SRF value or Safety Factor of 1.4 (Table 14).

Table 14. Pit slope analysis results are influenced by groundwater

\begin{tabular}{lll}
\hline Slope & Displacement $(\mathrm{m})$ & Critical SRF \\
\hline Low wall & 0.019 & 0.65 \\
High wall & 0.002 & 1.4 \\
\hline
\end{tabular}

\section{Conclusions}

The conclusions of this study are:

The value of the hydraulic head of the natural condition of the study area has a maximum yield of $+108 \mathrm{~m}$ ASL and a minimum of $+76 \mathrm{~m}$ ASL. The high hydraulic head is in the groundwater boundary area in the form of western and southern hills and the low hydraulic head is in the Biangan River. The distribution pattern of equipotential hydraulic head in the aquifers illustrate that the equipotential 
hydraulic head is getting lower and denser when it reaches the river system of Biangan.

Groundwater increases the weight of the slope that intensifies the material thrust force and reducing the shear strength of the slope material to prevent landslide. The reduction in rock strength and weak layer factors on the slope results in a reduction in rock mass that functions as a water seepage path. These cause landslide on the material which is below the groundwater level followed by the material above the groundwater afterwards.

The Critical SRF or Safety Factor value of the low wall which is influenced by groundwater is 0.65 with a total displacement of 0.019 meters. The Critical SRF value or a Safety Factor of the high wall which is influenced by groundwater is 1.4 with a total displacement of 0.002 meters.

The value of the Safety Factor or Critical SRF that is safe for the low wall is 7.79 with a total displacement of 0.02 meters, while the high wall has reached the Critical SRF value or a safe Safety Factor that is equal to 1.4 with a total displacement of 0.002 meters.

\section{References}

Alfreds R. Jumikis, 1983. Rock Mechanics (Second Edition). Clausthal-Zellerfeld.

Arif, I., 2016. Geoteknik Tambang. PT. Gramedia Jakarta, Jakarta.

Boonstra, J., Ridder, N.A. de, 1981. Numerical Modelling of Groundwater Basins, First. ed. International Institute for Land Reclamation and Improvement/ILR, Wageningen.

Devy, S.D., 2018. Hydrogeology of Karang Mumus Watershed in Samarinda, East Kalimantan Province, Indonesia. Forum Geogr. 32 https://doi.org/10.23917/forgeo.v32i1.5229

Devy, S.D., Sarungallo, C., 2018. Groundwater aquifer study on coal mining area: case of North Samarinda, Indonesia. J. Degrad. Min. L. Manag. 6, 1485-1495. https://doi.org/10.15243/jdmlm.2018.061.1485

Fabbri, P., Ortombina, M., Piccinini, L., 2012. Estimation of Hydraulic Conductivity Using the Slug Test Method in a Shallow Aquifer in the Venetian Plain (NE, Italy). Aqua Mundi 3, 125-133. https://doi.org/10.4409/Am-045-12-0048

Fetter, C.W., 2001. Applied hydrogeology (4th edn.). Prentice-Hall. Inc.
Hammer, M.J., MacKichan, K.A., 1981. Hydrology and quality of water resources., first. ed. John Wiiley \& Sons. Inc, Nabraska. $\quad$ https://doi.org/10.1016/03091708(83)90034-9

Haq, S., Prakasa, D., Putra, E., Hendrayana, H., Igarashi, T., 2011. Hydrogeology of an Open-pit Coal Mine in Tamiang Layang, Central Kalimantan, Indonesia: a Preliminary Groundwater Flow Modeling. Indones. Assoc. Geol. 1-20. https://doi.org/10.13140/RG.2.2.10002.15043

Harbaugh, A.W., 2005. MODFLOW-2005 : the U.S. Geological Survey modular ground-water model--the groundwater flow process, Techniques and Methods. https://doi.org/10.3133/tm6A16

Healy, R.W., Cook, P.G., 2002. Using Groundwater Levels to Estimate Recharge. Hydrogeol. J. 10, 92-109. https://doi.org/10.1007/s10040-001-0178-0

Hustrulid, W.A., Mccarter, M.K., Zyl, D.J.A. Van, 2001. Slope Stability in Surface Mining. https://doi.org/10.1145/1459359.1459574

Konikow, L.F., Reilly, T.E., 1999. Groundwater Modeling, Jacques W. ed. CRC Press LLC.

Lerner, D.N., 1990. Groundwater recharge in urban areas. Atmos. Environ. Part B, Urban Atmos. 24, 29-33. https://doi.org/10.1016/0957-1272(90)90006-G

Seiler, K.P., Gat, J.R., 2007. Groundwater Recharge from Run-Off, Infiltration and Percolation. Springer, Dordrecht, Netherland.

Spitz, K., Moreno, J., 1996. A Practical Guide to Groundwater and Solute Transport Modeling. John Wiiley \& Sons. Inc, Canada.

Supriyatna, S., Rustandi, E., 1995. Peta Geologi Lembar Samarinda, Kalimantan. Pusat Penelitian dan Pengembangan Geologi Bandung, HKI: B117921.

van Zuidam, R.A., van Zuidam-Cancelado, F.I., 1979. Terrain Analysis and Classification Using Aerial Photographs: A Geomorphological Approach, ITC textbook of photo-interpretation. International Institute for Aerial Survey and Earth Sciences.

Wyllie, D.C., Mah, C., 2004. Rock Slope Engineering, 4th edition, 4th ed. Spon Press, Taylor \& Francis Group, London and New York.

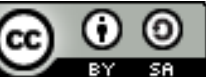

(C) 2021 Journal of Geoscience, Engineering, Environment and Technology. All rights reserved. This is an open access article distributed under the terms of the CC BY-SA License (http://creativecommons.org/licenses/by$\mathrm{sa} / 4.0 /$ ). 